\title{
Women neurologist
}

\section{A worldwide and Brazilian struggle}

\author{
Marleide da Mota Gomes'
}

\begin{abstract}
The main aim of this paper was to present some pioneer women neurologist, their struggle to pursue their career and the barriers mainly encountered at the beginning of their professional lives. It was also presented the progressive increasing of the feminine participation in medicine and in the neurology with study based on data of the School of Medicine of the Federal University of Rio de Janeiro and Brazilian Academy of Neurology. Their composition were analyzed according to gender, class and academic rank. In spite of this feminization, there is lack of a women's parallel advancement into leadership positions despite no visible barriers ("glass ceiling").
\end{abstract}

Key words: women, neurology, neuroscience, career.

\section{Neurologistas mulheres: uma luta mundial e brasileira}

\section{RESUMO}

O objetivo principal deste artigo foi apresentar algumas neurologistas pioneiras, a sua batalha para desenvolver a sua carreira e as barreiras encontradas principalmente no início de suas vidas profissionais. Foi também apresentado o progressivo aumento da participação feminina na medicina e na neurologia com estudo baseado em dados da Faculdade de Medicina da Universidade Federal de Rio de Janeiro e Academia Brasileira de Neurologia. Foi analisada a sua composição segundo gênero, nas classes e graus acadêmicos. Apesar dessa feminização, há falta de avanço paralelo de posições de liderança das mulheres, sem evidente barreira visivel ("teto de cristal").

Palavras-Chave: mulher, neurologia, neurociência, carreira.

In a democracy, there is a need that women and men should have equal opportunities, and gender equality is consequently a human right. However, gender role stereotypes are tenacious and help to perpetuate gender norms, in spite of objective evidence to the contrary ${ }^{1}$. There are examples as many obstacles, familiar or professional, may interfere in a neuroscience women career, as it was approached in the next sections.

\section{Career trajectories: "the pioneers"}

The career trajectories are unequal, and they depend on the time, place, purpose and personal profile, besides prejudices. Paul Julius Möbius (1853-1907) also published on gender determination: On the Physiological Feebleness of Women
$(1900)^{2}$. He advocated the idea that the smaller size of women's skulls, evidence, explained women's weaker intellect, a social concept. Within this spread concept began the career of two ladies: Blanche Edwards (1858-1941) and her classmate Augusta Klumpke (1859-1927), at the epicenter of the new born Neurologist: in Paris, in the 1800 's end ${ }^{2-6}$. Satran ${ }^{3}$ reported the struggle of these ladies to study medicine, hard contest for the medical residence and the determinants of the French Republic at the time that allowed bigger women freedom. Alfred Vulpian (18261887) was the dean of the Faculty of Medicine when Klumpke was interviewed for admission. He was against the acceptance of medical women student at that time ${ }^{2}$. The right to compete to the position of ex- 
tern was obtained after a vigorous campaign led by Edwards and her mother ${ }^{3}$. Edwards was also involved in the battle to the right to compete for the internship. Edwards and Klumpke successfully completed their written and public-oral examination for the externship $(1882)^{4}$. Edwards worked under Charcot's supervision, her thesis advisor, at the Salpetrière (1884-1885) ${ }^{4}$. Ironically, Klumpke was positioned in the Vulpian's Service. Goetz ${ }^{3}$ noted that there is an article related to the Charcot's personal pride in Edward's accomplishments, and his proposal of a full integration of women students into the medical field, although he claimed that certain medical duties remained difficult for a woman to fulfill. In spite of her brilliance, Edwards did not win twice the neurological internship competition, but was a distinguished physician of women and children and a women's rights activist. Augusta Klumpke became the first female intern of the hospitals of Paris (1886) after her second competition ${ }^{2-4}$. The intervention by the minister of Public instruction and worship and leftist radical scientist, Paul Bert (18301886), was of the utmost importance for this women's achievement ${ }^{3}$. Satran ${ }^{3}$ emphasized that "neither medical progress nor social changes result from passive acceptance of the status quo". Klumpke struggled to occupy the space that deservedly took, even against the opposition of Edmé Felix Alfred Vulpian (1826-1887), the insecure one of Jean-Martin Charcot (1825-1893), in spite of having the maintained support of Louis Théophile Joseph Landouzy (1845-1917), and Joséph Jules Déjerine (1849-1917), on behalf of more participation of women inside the hospitals of Paris. Satran ${ }^{3}$ quoted that the oppositions for the women's position at the neurology were supported by weak arguments, such as it would take a woman intern on night call too long to dress herself to respond to an emergency, and the most embarrassing, that the competition of women would threaten the male practice of medicine. This lead to the question of gender discrimination and even sexual harassment during preclinical and clinical coursework: more women reported such behavior across all training contexts, but self-assessed impact on career tended to be slightly larger for men according to the study of Stratton et al. ${ }^{7}$. The same authors expressed that these obstacles in residency selection were most prevalent in obstetrics and gynecology (men and women), general surgery (women), and maybe in neurology (women). Sandra Olson ${ }^{5}$, the $1^{\text {st }}$ woman president of the American Academy of Neurology (AAN) gave a deposition in which she testified about the "little harassment and discrimination" that she suffered from her professors and peers at the beginning of her career.

In Brazil, only one woman among 47 neurologists participated in the founding of the Brazilian Academy of Neurology (ABN): Eurydice Magalhães Borges Fortes. More recently, Newra Tellechea Rotta (1990-1992) and Elza Dias Tosta da Silva (2008-2012) were appointed as the first and second $\mathrm{ABN}$ woman president (20082012). It is remarkable, that in almost 50 year, the ABN nominated only two female presidents. At the beginning of this Society, this was justifiable because women constitute the minority of the members. In 2002, it was appointed the first woman as full professor of child neurology in Brazil: Maria Valeriana Moura Ribeiro. She was followed by Umbertina Conti Reed (2006) and Marilisa Mantovani Guerreiro (2007). The first and the latter are from the Faculdade de Ciências Médicas da Unicamp, and Umbertina Conti Reed from Faculdade de Medicina da Universidade de São Paulo. Leila Chimelli (1998) was the first full female professor of neuropathology from the Faculty of Medicine of the Federal University of Rio de Janeiro. In 2010, from the members of the ABN, about $38 \%$ were women. The different proportion between men and women is higher in the more differentiated class (Fig 1).

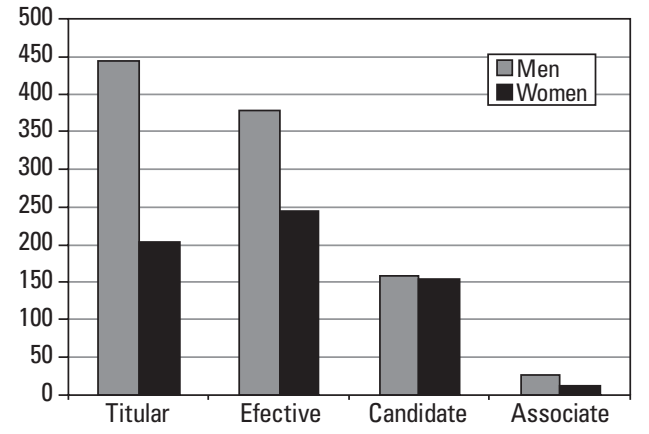

Source data: Brazilian Academy of Neurology, office.

Fig 1. Member of the Brazilian Academy of Neurology, 2010, according to sex and rank.

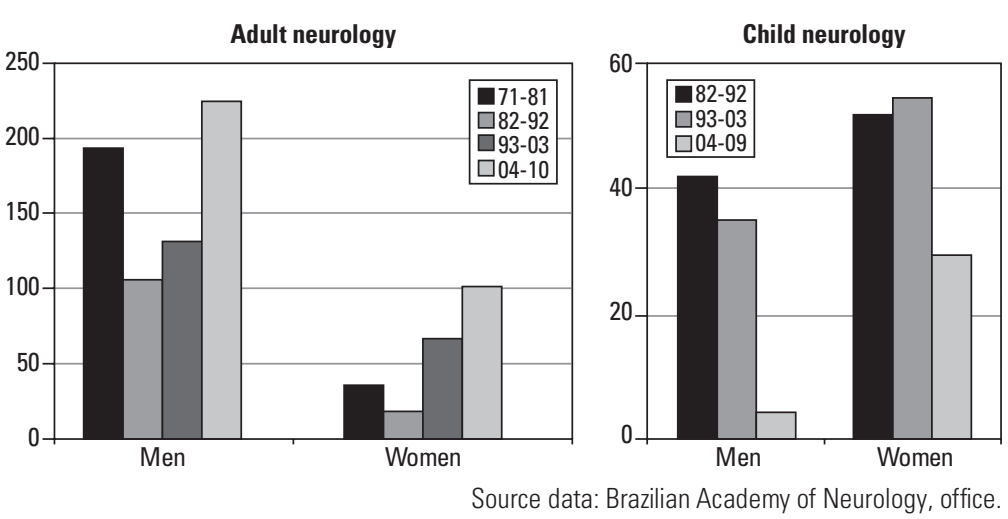

Fig 2. Specialists of the Brazilian Academy of Neurology according to sex, period, adult neurology or child neurology. 
Table. Sex composition of the Brazilian Academy of Neurology by Scientific Departments.

\begin{tabular}{|c|c|c|c|c|c|c|}
\hline \multirow{2}{*}{$\begin{array}{l}\text { Scientific } \\
\text { Department }\end{array}$} & \multicolumn{3}{|c|}{$\begin{array}{c}\text { Scientific } \\
\text { Department } \\
\text { Coordination }\end{array}$} & \multicolumn{3}{|c|}{$\begin{array}{c}\text { Scientific } \\
\text { Department } \\
\text { Members }\end{array}$} \\
\hline & $M$ & $\mathrm{~F}$ & $M: F$ & $M$ & $\mathrm{~F}$ & $M: F$ \\
\hline Stroke & 2 & 1 & 2 & 233 & 81 & 2.9 \\
\hline Headache & 2 & 1 & 2 & 200 & 87 & 2.3 \\
\hline Cognition & 2 & 1 & 2 & 188 & 69 & 2.7 \\
\hline Infectious & 3 & 0 & $\sim$ & 50 & 30 & 1.7 \\
\hline Doppler & 1 & 2 & 0.5 & 50 & 23 & 2.2 \\
\hline Pain & 3 & 0 & $\sim$ & 60 & 27 & 2.2 \\
\hline Epidemiology & 3 & 0 & $\sim$ & 26 & 12 & 2.2 \\
\hline Epilepsy & 2 & 1 & 2 & 177 & 93 & 1.9 \\
\hline Physiology & 3 & 0 & $\sim$ & 157 & 90 & 1.7 \\
\hline Genetics & 3 & 0 & $\sim$ & 30 & 18 & 1.7 \\
\hline History & 2 & 1 & 2 & 25 & 7 & 3.6 \\
\hline Immunology & 1 & 2 & 0.5 & 107 & 43 & 2.5 \\
\hline Child & 1 & 2 & 0.5 & 62 & 61 & 1.0 \\
\hline Cerebrospinal fluid & 1 & 2 & 0.5 & 34 & 14 & 2.4 \\
\hline Motoneuron & 3 & 0 & $\sim$ & 41 & 13 & 3.2 \\
\hline Movement & 2 & 1 & 2 & 143 & 46 & 3.1 \\
\hline Muscular & 2 & 1 & 2 & 67 & 48 & 1.4 \\
\hline Per. Neuropathy & 1 & 2 & 0.5 & 73 & 32 & 2.3 \\
\hline Neurorehabilitation & 3 & 0 & $\sim$ & 26 & 16 & 1.6 \\
\hline Sleep & 2 & 1 & 2 & 27 & 20 & 1.4 \\
\hline Total & 42 & 18 & 2.3 & 1776 & 830 & 2.1 \\
\hline
\end{tabular}

Note: $A B N$ members may be engaged in more than one SD. The relationship of the all members of the $\mathrm{ABN}$, men:women:1.6. Source data: Brazilian Academy of Neurology, office. M: masculine; F: feminine.

In the same Academy, $\mathrm{ABN}$, there is a feminization of its members. However, men dominate in the adult neurology specialist, but in the children's, a subspecialty that is collapsing, women have always predominated (Fig 2). Gender non equality is also common among important medical Journals ${ }^{8}$, in spite the increasing female participation in paper authorship 9 . In Arquivos de NeuroPsiquiatria, the Editorial Board were composed by $17 \%$ of women, as Neurology, linked to the AAN. The Fig 3 data demonstrates the remarkable differences that still exist in academic representation: a classical "glass ceiling".

An aspect to be studied is the favoritism given by the ABN associates to the sub-specialty/scientific department within Neurology, according to sex (Table).

\section{Conclusion}

The struggle for sexual equality in the Neurology continues, despite the women's improvement. For the reduction or even the elimination of gender inequalities, educational and maybe affirmative actions are needed. Obviously, all the proposals have to be analyzed under

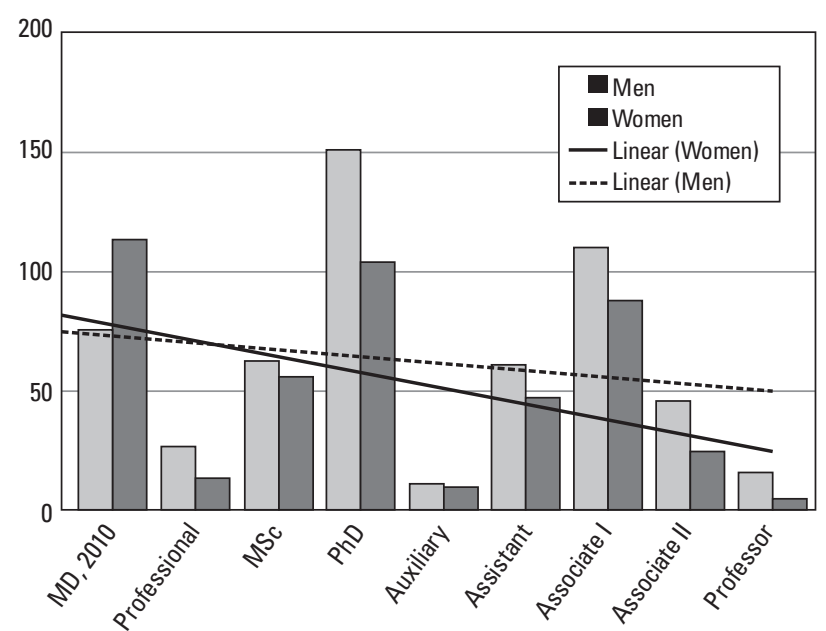

Source data: Faculty of Medicine of the Federal University of Rio de Janeiro, office.

Fig 3. Representativeness of the medical doctor formed and faculty members at faculty positions according to gender, academic rank at Faculty of Medicine of Federal University of Rio de Janeiro, the biggest and pioneer Brazilian Federal University.

the supervision and participation of committees of female representatives. Other incentives include, for instance, the mentoring, an important tool in promoting women and other minorities' academic excellence.

ACKNOWLEDGMENTS - I gratefully acknowledge the invaluable help of the following people: Mrs. Simone Osti from Brazilian Academy of Neurology, Mrs. Vania Rocha from Office of Human Resources of Faculty of Medicine of Federal University of Rio de Janeiro, Mr. Judas Tadeu T. Barbosa from the Academic Office of the same Faculty for sent to me the requested data; Professor Marilisa Mantovani Guerreiro to her update of the full professor women of the Brazilian neurology.

\section{REFERENCES}

1. Carnes M, Morrissey C, Geller SE. Women's health and women's leadership in academic medicine: hitting the same glass ceiling? J Womens Health 2008;17:1453-1462.

2. Whonamedit? A dictionary of medical eponyms. http://www.whonamedit.com/

3. Satran R. Augusta Dejerine-Klumpke: first woman intern in Paris hospitals Ann Intern Med 1974;80:260-264.

4. Goetz CG. Charcot and the myth of misogyny. Neurology 1999;52:16781686.

5. Olson SF. Women in neurology. Neurology 2005;65:344-348.

6. Gomes MM. Mulheres nas neurociências. In: Marcos históricos da neurologia. Rio de Janeiro: Editora Científica Nacional, 1997: 185-188.

7. Stratton TD, McLaughlin MA, Witte FM, Fosson SE, Nora LM. Does students' exposure to gender discrimination and sexual harassment in medical school affect specialty choice and residency program selection? Acad Med 2005;80:400-408.

8. Carroll CB, Tengah DS, Lawthom C, Venables G. The feminisation of British neurology: implications for workforce planning. Clin Med 2007;7:339-342

9. Takayanagui OM, Livramento JA. The increasing female participation in authorship of articles published in neurology in Brazil. Arq Neuropsiquiatr 2009;67:914-916. 